\title{
Inducible T-Cell Costimulator
}

National Cancer Institute

\section{Source}

National Cancer Institute. Inducible T-Cell Costimulator. NCI Thesaurus. Code C94803.

Inducible T-cell costimulator (199 aa, $23 \mathrm{kDa}$ ) is encoded by the human ICOS gene. This protein is involved in the regulation of T-cell antigen-mediated responses. 